\title{
Environmental justice research shows the importance of social feedbacks in ecosystem service trade-offs
}

\author{
$\underline{\text { Neil M. Dawson }}^{1}, \underline{\text { Kenneth Grogan }}^{2}, \underline{\text { Adrian Martin }}^{1}$, Ole Mertz $^{2}, \underline{\text { Mava Pasgaard }}^{2}$ and Laura Vang Rasmussen $^{2}$
}

\begin{abstract}
In this article, we shine a spotlight on approaches to research ecosystem service trade-offs and critically assess their representation of relevant social dynamics. Although studies linking ecosystem services and human well-being have provided theoretical insights into social and ecological trade-offs, we argue that ecosystem services research has paid insufficient attention to "social feedbacks," people's cognitive and behavioral responses to change. We demonstrate that augmenting ecosystem services research with environmental justice approaches (exploring perceptions of the distribution of costs and benefits, decision making procedures, and recognition of different values and identities) can more effectively capture important responses to ecosystem governance. Spatial analysis of land use change, mixed-method assessment of multidimensional well-being, and qualitative environmental justice research were applied in three villages adjacent to Nam Et-Phou Louey National Protected Area in northern Laos. Spatial analysis showed that, from 2006 to 2015, forest clearance for cultivation remained stable within the protected area. Well-being assessment revealed the local population benefited from rapidly increasing incomes, asset ownership, and reduced poverty during that time. In combination, spatial and well-being analyses paint a picture of limited trade-offs, despite growing incentives to exploit protected land and resources through cash crops and high-value forest products. In contrast, results from environmental justice research revealed profound trade-offs between conservation and local practices, and highlight governance deficiencies relating to procedure and recognition. Consequently, formal protected area rules were perceived to be illegitimate by many and actively undermined, for example through negotiated access with alternative authorities. We conclude that although well-being research provides an essential foundation to understand diverse attachments to natural resources, the addition of environmental justice research can reveal local perceptions and social feedbacks critical to ecosystem service trade-offs, and highlight pathways to reconcile them through satisfying stakeholders' diverse, dynamic objectives.
\end{abstract}

Key Words: conservation and development; conservation impact; equity; governance; Lao PDR; mixed methods; Nam Et-Phou Louey; protected area; rights-based conservation; social assessment; well-being

\section{INTRODUCTION}

Ecosystem service trade-offs occur because ecosystems and human well-being are interdependent, and institutional and ecological change cause both positive and negative impacts upon components of the ecosystem and different stakeholders (Rodríguez et al. 2006, Nelson et al. 2009, Raudsepp-Hearne et al. 2010, Galafassi et al. 2017). Assessment of trade-offs likely to occur through changes, including governance interventions, is therefore necessary so that unfavorable impacts can be avoided, minimized, or mitigated (Carpenter et al. 2009, McShane et al. 2011, Howe et al. 2014). However, research approaches are diverse and may provide very different understandings of the nature of trade-offs and imply contrasting solutions to address them (Norgaard 2010, Lele et al. 2013). Indeed, the application of research to manage trade-offs in practice has been rare, suggesting a need to critically assess and further develop approaches to represent the social and ecological dynamics relevant to tradeoffs (Opdam et al. 2013, Albert et al. 2014, Guerry et al. 2015).

Ecosystem service research has produced theoretical understanding of the dynamic links and trade-offs between ecosystems and human well-being (Raudsepp-Hearne et al. 2010, Polishchuk and Rauschmayer 2012). Spatial analyses of land use have been used to represent the availability of ecosystem services to stakeholders through mapping the ecological structures underpinning those services (Hein et al. 2006, Lawler et al. 2014). Changes in landscape governance or economic incentives may result in extensive changes in land use, which through such analyses can be quantified and used to indicate impacts on ecosystem services and resulting trade-offs (Rodríguez et al. 2006, de Groot et al. 2010). For example, conversion of forests to agriculture indicates greater availability of farm-related services for some stakeholders while potentially restricting provisioning, regulating, and cultural services for others, including availability of forest products, climate regulating services, and opportunities for wildlife tourism.

A growing body of research on human well-being and links to ecosystem services has complemented spatial analyses through deeper understanding of the social dimensions of trade-offs (Woodhouse et al. 2015). Well-being studies extend beyond quantitative representation of material aspects of people's lives and commonly employ qualitative or mixed methods to assess subjective values and relational well-being (de Lange et al. 2016). In practical terms, such approaches consider the various social, cultural, human, and environmental resources people can utilize to attain basic needs and a satisfactory quality of life, including attention to the different social and cultural values that underpin those subjective priorities (Gough and McGregor 2007, Coulthard et al. 2011). Studies using this approach have revealed (a) the diversity of values and perspectives among stakeholders, including the poorest and most marginal local people, (b) the contribution of different land use types to the various stakeholders' well-being, and (c) power relations between stakeholders (Leach et al. 2012, Opdam et al. 2013, Wu 2013, Dawson and Martin 2015, Berbés-Blázquez et al. 2016, Boonstra 2016).

${ }^{1}$ School of International Development, University of East Anglia, ${ }^{2}$ Department of Geosciences and Natural Resource Management, University of Copenhagen 
We suggest the need for ecosystem services research to extend beyond such approaches, specifically to better capture how people perceive and respond to change, which in ecosystem service science have been termed "social feedbacks" (e.g., Pascual et al. 2014). The importance of exploring cognitive and behavioral responses to inform policy interventions has long been recognized by scholars of social psychology (Bandura 1986, Haidt 2007), and been related to environmental policy and behavior (Stern 2000, Kollmuss and Agyeman 2002). These studies contend that people's perceptions of and responses to change are not determined solely by the trajectories they influence in a person's material or even relational well-being. Although an individual's socioeconomic status and socio-cultural values are influential in their attitude and behavioral responses, they do not form a simple causal chain (Stern 2000). Beyond the factors common to wellbeing approaches, cognitive judgements and behavioral responses are additionally influenced by a range of sometimes competing social norms or moral judgements, notions of what is fair and just, contextual factors including cogent social and political discourses, and perceived opportunities, incentives, threats, and costs (Bandura 1986, Stedman 2002). Some authors have included perceptions of governance and views about fairness within wellbeing frameworks (Biedenweg et al. 2017). However, most academic conceptualizations of well-being focus on a person's long-term functioning, abilities, accomplishments, and values at the expense of exploring shorter term subjective feelings, judgements, and behavioral responses (Deci and Ryan 2008, Huta and Waterman 2014).

Social feedbacks can serve either to positively reinforce ecosystem governance or negatively compromise it and can therefore determine the sustainability of solutions, and whether interventions are perceived as just and supportable by multiple stakeholders. For example, the Birds Nest Protection program in Cambodia provided incentives for local egg collectors to selfregulate resource collection and even protect nests to sustain the declining population. The scheme was perceived as fair by local inhabitants resulting in greater cooperation and improved ecological outcomes, a positive social feedback (Clements et al. 2010). In contrast, a conservation intervention perceived to be unfair may even lead to killing of wildlife as a form of protest, as recorded for elephants in Tanzania (Mariki et al. 2015).

Prominent ecosystem services studies have recognized that social feedbacks may have a crucial influence on the achievement of ecological outcomes commensurate with social objectives. The United Kingdom National Ecosystem Assessment (2011) includes reference to social feedbacks in the guiding conceptual framework, in which feedbacks are seen to act as a driver of change in response to impacts on human well-being. Pascual et al. (2014) present a framework for understanding social and ecological effects of payments for environmental service schemes that recognizes feedbacks as positive or negative. The authors list examples of feedbacks including perceptions of legitimacy, compliance, resistance, corruption, and manipulation. However, beyond these references, social feedbacks have been poorly elaborated and seldom researched.

To capture social feedbacks in ecosystem services research, we propose the addition of an environmental justice framework. Environmental justice research, from its origins looking at issues surrounding environmental pollution in the United States, is being increasingly applied to ecosystem governance around the globe (Sikor et al. 2014, Martin et al. 2016). Studies of environmental justice explore people's perceptions of and justice claims made about issues, policies, debates, or institutions through primarily qualitative methods with reference to three interrelated dimensions: (1) the distribution of costs, benefits, and risks; (2) the procedures, both formal and informal, through which decisions are made; and (3) recognition of people's varying experiences, identities, and values (Walker 2012, Schlosberg 2013). Attention to justice claims in terms of these three dimensions, made in relation to changes in people's lives, is well suited to produce understanding of their cognitive and behavioral responses (Walker 2009).

To demonstrate the potential contribution of environmental justice research, we provide insights from an interdisciplinary mixed-method research program conducted in 2014-2015 around Nam Et-Phou Louey National Protected Area (hereafter NEPL), a montane forest in northern Laos. Through the case study we demonstrate the different, though also complementary, understanding of trade-offs that various research approaches bring (Fig. 1). Three methods were used: (1) spatial analysis to quantify landscape changes in the wake of protected area boundary demarcation and changes to cash cropping; (2) mixedmethods, including focus groups and individual semistructured interviews to assess local people's well-being and changes over the previous 10 years; and (3) semistructured interviews to explore views expressed by local people about protected area governance, in terms of distribution, procedure, and recognition, the three dimensions of environmental justice.

Fig. 1. An integrated environmental justice and well-being approach. Spatial analysis and mixed methods well-being assessment are supplemented with a qualitative environmental justice approach to uncover social feedbacks and provide additional understanding of trade-offs.

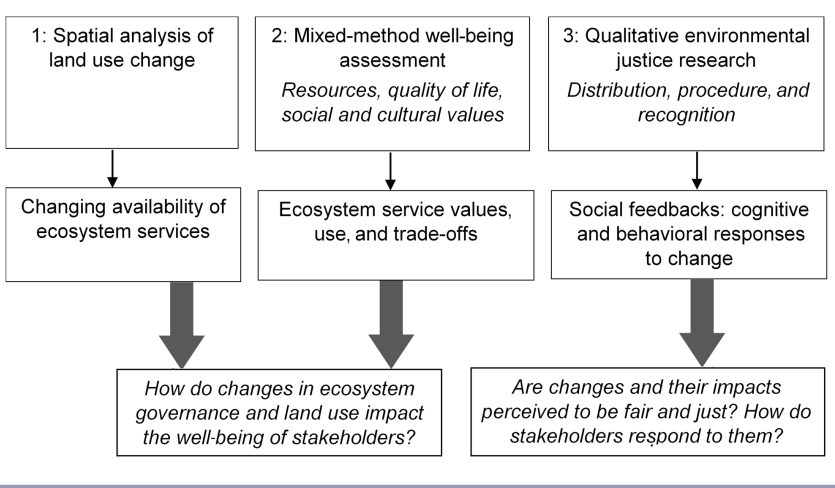

\section{METHODS}

\section{Study site}

Our study focused on the landscape around NEPL in Huaphan Province in northeastern Lao PDR (Fig. 2), where poverty is still prevalent and local people's links to natural resources are strong and diverse (Broegaard et al. 2017a). As recently as the 1980s, many people relied heavily upon hunting, foraging, and shifting rice cultivation within the now protected NEPL (Castella et al. 2013). The area hosts numerous ethnic groups falling under three 
Table 1. Socioeconomic data by village.

\begin{tabular}{|c|c|c|c|c|}
\hline & $\begin{array}{l}\text { Phon Song (total } \\
\text { protection zone) }\end{array}$ & $\begin{array}{c}\text { Khorn Ngua } \\
\text { (controlled-use zone) }\end{array}$ & Son Khua (ecotourism) & Average/Total \\
\hline Number of households in village & 50 & 60 & 178 & 288 \\
\hline Number interviewed & 30 & 30 & 40 & 100 \\
\hline Ethnicity of 100 interview respondents & $\begin{array}{c}\text { Lao Loum } 26 \\
\text { Khmu } 3 \\
\text { Black Tai } 1\end{array}$ & Khmu 30 & $\begin{array}{c}\text { Lao Loum } 14 \\
\text { Khmu } 23 \\
\text { Red Tai } 3\end{array}$ & $\begin{array}{c}\text { Lao Loum } 40 \\
\text { Khmu } 56 \\
\text { Red Tai } 3 \\
\text { Black Tai } 1\end{array}$ \\
\hline $\mathrm{MPI}^{\dagger}$ average 2014 (2004) & $0.22(0.42)$ & $0.22(0.42)$ & $0.18(0.42)$ & $0.20(0.42)$ \\
\hline Ownership of television 2014 (2004) & $83 \%(0 \%)$ & $93 \%(3 \%)$ & $80 \%(8 \%)$ & $85 \%(4 \%)$ \\
\hline Ownership of motorbike 2014 (2004) & $80 \%(0 \%)$ & $83 \%(3 \%)$ & $73 \%(5 \%)$ & $78 \%(3 \%)$ \\
\hline $\begin{array}{l}\text { Average total farming income in million } \\
\text { Kip (with standard error) }\end{array}$ & $5.63(0.80)$ & $8.81(1.04)$ & $7.05(1.09)$ & 7.15 \\
\hline $\begin{array}{l}\% \text { of households in receipt of nonfarm } \\
\text { income in } 2014\end{array}$ & $33 \%$ & $46 \%$ & $63 \%$ & $49 \%$ \\
\hline $\begin{array}{l}\text { Average NTFP }{ }^{\dagger} \text { income in } 2014 \text { in million } \\
\text { Kip/\% of earning households }\end{array}$ & $1.27 / 87 \%$ & $1.44 / 100 \%$ & $0.67 / 40 \%$ & $1.08 / 74 \%$ \\
\hline
\end{tabular}

broad umbrellas: Lao Loum, Khmu, and Hmong-Mien (Johnson 2012). Primarily during the 1980 s, all remote villages were relocated alongside built or planned roads to allow for development and easier governance by the central communist leadership (Castella et al. 2013). Exclusionary conservation interventions since the 1990s restricted the high levels of use of a range of forest products by local populations (Vongvisouk et al. 2016). Alongside conservation came policies to transform shifting cultivation of upland rice, which characterized the region's food production and primary livelihood, to more sedentary, continuous farming, though these policy goals were scarcely enforced (Broegaard et al. 2017b). More recently, the region has seen a widespread change to cash cropping as merchants encouraged the planting of maize to feed livestock in Vietnam (Vongvisouk et al. 2016). To promote land use compatible with conservation of forests, consultative land use planning exercises are held roughly every 5 to 10 years involving local government officials, conservation managers, and villagers (Lestrelin et al. 2012, Broegaard et al. 2017b).

We focused on three villages adjacent to the protected area representing different forms of ecosystem governance associated with NEPL (Fig. 2). The villages comprise inhabitants practicing a variety of land and natural resource uses (Rasmussen et al. 2016, 2017, Broegaard et al. 2017a) and from several ethnic groups (Table 1). Phon Song lies adjacent to a Total Protection Zone (TPZ) in which no access is allowed. Khorn Ngua lies adjacent to a Controlled-Use Zone (CUZ). Son Koua, a larger village situated on a paved road, also lies adjacent to the CUZ but additionally has an ecotourism project operating in the village that provides employment and trade opportunities to some villagers and involves a revenue sharing scheme through which tourism revenue is distributed annually so long as rules for forest clearance and hunting are adhered to.

\section{Data collection methods}

Remote sensing analyses of land use change at the village level We mapped annual land use change from 2006 to 2015 for each of the three villages and adjacent land inside the protected area.
The protected area boundaries were formally delineated in the three villages in 2008 and large proportions of villagers began producing maize as a cash crop in 2010. The aim of the analysis was to establish the impacts of changes in governance and economic incentives on land use. Specifically, we quantified the extent of forest and fallow clearances for crops or livestock (two of the major ecosystem services derived by local people) both within and outside of the protected area.

Fig. 2. Map of study area.

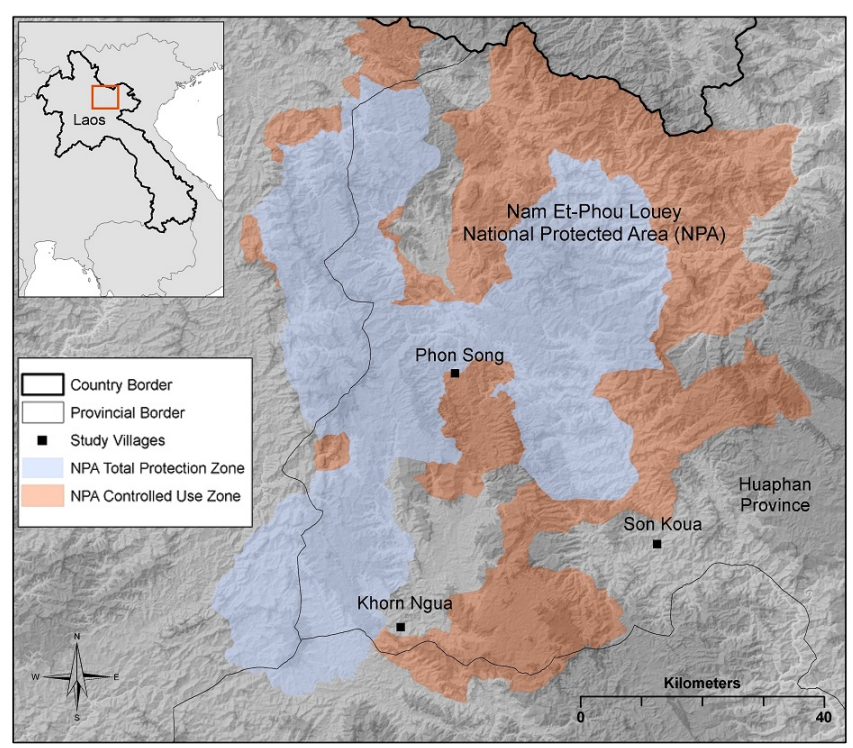

We used the extensive Landsat archive. Using Landsat imagery, forest fallow is difficult to distinguish from mature forest after two to four years of regrowth (Hett et al. 2012). We therefore used a dense time series change detection algorithm based on annual cloud-free image composites described in detail by Broegaard et al. (2017a). We first used random forests (Breiman 2001) to 
classify imagery from the base year 2005 into three classes: forest, cropland, and other land. To map fallow land for the same base year we analyzed annual imagery from 1989 to 2005. This extended historical analysis allowed effective mapping of the fallow area for the base year. We then continued the time series analysis from 2006 to 2015 to track annual changes in forest, fallow land, and cropland for each of the three villages. Protected area and village boundaries were obtained through NEPL staff and provincial authorities. We used them to detect changes within and outside of the protected area.

\section{Mixed-method assessment of well-being and the contribution of} ecosystem services

Fieldwork was conducted between February 2014 and July 2015. We undertook an initial period of trust-building with leaders and inhabitants in the three villages. It was important to emphasize our position as researchers acting independently of government, protected area management, and law enforcement, particularly where contravention of formal regulations was common practice. We highlighted the aims and scope of the research, choice to withdraw participation at any stage, and steps to be taken to ensure anonymity of respondents. Key informant interviews and participant observation enabled researchers to learn about the local context during the initial phase of research. This understanding was then consolidated through two focus groups in each village. The first comprised participatory mapping exploring local land use, perceived changes in the landscape and governance of it. The second aimed to understand local priorities for living well and the most significant changes that had affected people's lives over the past decade. Between 8 and 12 adult respondents were selected randomly from lists held by village heads and asked to participate voluntarily. Males and females were asked and represented in equal numbers. Results of the focus groups were used to inform design of semistructured interviews.

Semistructured interviews were conducted to assess and explore in greater detail variation in well-being, diversity of values, the changing relationship between ecosystem services and well-being, and concurrently to enable expression of people's perceptions of environmental justice. Interviews were conducted with adults from 100 households across the three villages, 30 in each of Phon Song and Khorn Nhua and 40 in the larger Son Koua village (Table 1). Households were selected randomly from lists held by village heads and either adult male or female asked to participate voluntarily. Allocating the choice of respondent to householders resulted in a smaller proportion of female respondents, 24 out of 100. Ten respondents from each village were randomly selected for a second interview to validate findings and further explore their family's recent history and any pertinent issues raised in greater detail.

During semistructured interviews, we collected both quantitative and qualitative data to represent levels of poverty, well-being, and the changing contribution made by provisioning, regulating, and cultural services. We conceptualized well-being along the lines of Gough and McGregor (2007) and presented as a framework by Dawson and Martin (2015) to focus on: (a) the various resources people have access to (economic, human, natural, social, and cultural); (b) their ability to meet basic human needs and the quality of life they achieve and aspire to; and (c) their subjective perceptions, based on individual experiences and agency as well as social and cultural values, of what they have and quality of life they experience. Quantitative socioeconomic data was collected to represent the material resources each participant had obtained or had access to, including land and farming income. To represent ability to meet basic needs, we measured the multidimensional poverty index for each household, which focuses on universal indicators for health, nutrition, education, housing standards, access to energy, fuel, sanitation, and ownership of various assets (Alkire and Santos 2014). These data were recorded for 2014 when interviews took place and through recall we explored changes in selected resources since 2004. To enhance the reliability of recalled answers, additional questioning was used to establish the first year they had owned an asset, to give more detailed description (of the asset, circumstances, or implications for their lives), to explore reasons for changes (e.g., sold because of wedding costs, received large sum of money), or to verify with a second source when feasible (Dex 1995).

\section{Qualitative environmental justice research}

We explored respondents' feelings about and behavioral reactions to ecosystem governance, and interrelated changes, through the same semistructured interviews as well-being assessment. A set of open questions explored perceptions of the procedures, both formal and informal, through which decisions are made, recognition of different identities and values in those processes and decisions, and the outcomes they experienced in terms of the distribution of material and nonmaterial costs, risks, and benefits, i.e., the three dimensions of environmental justice. This elicited understanding of social feedbacks in terms of people's cognitive responses to political, environmental, economic, and technological, social, and demographic changes and their resulting behavior (such as compliance, active participation, avoidance, or efforts to undermine).

All interviews and focus groups were conducted in Lao language by two Lao researchers, one female and one male. Answers were noted in Lao and later translated into English. Consent was recorded, though interviewers emphasized that respondents could refuse to participate or answer specific questions at any time. Once interview transcripts had been translated, we coded responses in QSR NVIVO 10 (QSR 2012). We allocated interview and focus group responses to the various concepts forming the well-being framework and the three dimensions of environmental justice: procedure, distribution, and recognition. Because some categories are interrelated, responses could potentially be coded to several concepts and subsequent checks were made to ensure allocations were correct and complete. Key themes were drawn inductively and comparisons made between those pools of data. One-way analyses of variance were conducted on quantitative data to detect significant intervillage differences as well as changes over time.

\section{RESULTS}

Remote sensing analyses of land use change at the village level Remote sensing revealed the amount of forest and fallow land cleared for cultivation both within and outside of the protected area zones for each village from 2006 to 2015. On average, for all three villages, 0.7 hectares of land were cleared per household per annum within the TPZ and 1.16 hectares in the CUZ. Of the combined total of 1.87 hectares cleared per household per year inside the protected area (Table 2), 78\% related to clearance of 
Table 2. Land use change for protected area and village land (hectares per household per annum) for each village for the 10 years from 2006 to 2015. Standard errors are displayed in brackets.

\begin{tabular}{|c|c|c|c|c|}
\hline & $\begin{array}{c}\text { Phon Song } \\
\text { (50 households) }\end{array}$ & $\begin{array}{c}\text { Khorn Ngua } \\
\text { (60 households) }\end{array}$ & $\begin{array}{c}\text { Son Koua } \\
\text { (178 households) }\end{array}$ & $\begin{array}{l}\text { Total average ( } 288 \\
\text { households) }\end{array}$ \\
\hline Forest in TPZ & $0.45(0.08)$ & $0.37(0.14)$ & $0(0)$ & 0.15 \\
\hline Fallow in TPZ & $1.7(0.23)$ & $1.22(0.19)$ & $0(0)$ & 0.55 \\
\hline Total in TPZ & 2.16 & 1.58 & 0.00 & 0.70 \\
\hline Forest in CUZ & $0.4(0.07)$ & $0.34(0.10)$ & $0.19(0.03)$ & 0.26 \\
\hline Fallow in CUZ & $2.06(0.13)$ & $0.88(0.18)$ & $0.59(0.05)$ & 0.91 \\
\hline Total in CUZ & 2.46 & 1.22 & 0.78 & 1.16 \\
\hline $\begin{array}{l}\text { Total land clearance in protected area per } \\
\text { household }\end{array}$ & 4.61 & 2.80 & 0.78 & 1.87 \\
\hline Forest in village land & $0(0)$ & $0.31(0.07)$ & $0.17(0.03)$ & 0.17 \\
\hline Fallow in village land & $0(0)$ & $4.29(0.40)$ & $2.03(0.24)$ & 2.15 \\
\hline
\end{tabular}

$\mathrm{TPZ}=$ Total Protection Zone; CUZ = Controlled-Use Zone.

previously farmed fallows and $22 \%$ to clearance of older forest. Although forest clearance was continuing, the analysis showed that deforestation within NEPL was relatively stable, having occurred evenly throughout the period 2006-2015. Comparing up to and after 2008, when the protected area boundaries were delineated, analysis of variance showed no significant decrease in rates of clearance per year for any village. Nor were there significant increases in rates of clearance for each village within the TPZ, CUZ, or outside the protected area after households began cultivating maize for sale in 2010 .

The level of clearance within the protected area (all in contravention of the protected area rules) differed considerably by village. Phon Song, the village adjacent to the TPZ, exhibited significantly higher clearance rates per household than Khorn Ngua, adjacent to the CUZ ( $p=0.01, F=7.87$ ). Cleared areas comprised primarily fallow and even around Phon Song less than half a hectare of forest was cleared per household per annum within the TPZ (Table 2). Clearance rates were lowest for Son Koua (Table 2; significantly lower than Khorn Ngua, $\mathrm{p}<0.001$, $\mathrm{F}=17.11$ ), which also had a CUZ as a buffer and where an ecotourism program operated. Ecotourism provided employment opportunities and limited revenue sharing, based on compliance with rules governing hunting, fishing and forest clearance.

\section{Assessment of well-being trends and implications for ecosystem service trade-offs}

Focus groups revealed consistency in resources prioritized to live a good life within and between villages. Access to farmland to produce rice for subsistence and maize for income was a major priority. Opportunities for additional income from nonfarm work (trading, forestry, construction, and so on) were becoming more highly valued. Access to natural resources from forests, farmland, and rivers for food, construction, household items, and medicines were considered essential for use and, by many, for sale. Good cooperation within and between villages and with authorities was emphasized, particularly in the face of prior conflict. Access to electricity, clean water, schools, health centers, and roads were also highly valued.

Both quantitative and qualitative analyses of changes in wellbeing elicited limited expression of trade-offs between protected area governance and local people, and furthermore indicated potentially synergistic trends with conservation. Importantly, positive trajectories in material well-being and alleviation of poverty occurred alongside increased restrictions on forest use. Interview respondents unanimously expressed support for forest conservation in principle. People cited beneficial contributions of the forest to their well-being through regulation of climate and water, avoided negative impacts of deforestation on land and soil, and the importance of protecting biodiversity for future generations, primarily for continued availability of provisioning services to their children and grandchildren. In Son Koua $63 \%$ of interviewees noted the importance of tourism and the income provided or that could potentially be earned. These positive contributions of the protected area were perceived, over the long term, to outweigh instances of negative impacts from the protected area on access to farm land, resource collection, and through wild animals raiding crops and causing occasional harm to livestock. Moreover, rather than aspiring to increase activities in the forest, interview respondents across all villages expressed aspirations for their children to find employment outside of farming and away from the forest because of the arduous work and low, uncertain returns from shifting cultivation. They described a priority to invest in their children's education to enable them to gain government salaried jobs such as teachers and policemen, suggesting further reduction in trade-offs between conservation and local livelihoods in the future.

In terms of cultural values, villagers expressed very limited attachment to the protected forest or anything inside it. Instead they perceived that resources were commonly collected because of lack of alternatives, the near absence of accessible markets at which to buy those products, or the inability to afford items such as meat or building materials. This view was consistently reported across all three villages. Our findings from ethnographic methods such as participant observation and informal discussions contrastingly suggest that attachments to specific valued places and activities such as hunting, fishing, and other uses of natural resources from local forests, including traditional medicines and materials to make rice baskets, sieves, fish traps, and other household items, do have some cultural significance. Yet, in support of the expressed views of respondents, many of those materials or alternatives were available outside of the protected area and were only collected by a very small number of specialists who continued to pass on this traditional knowledge within their own family. The loss of cultural connection may also have been 
influenced by the resettlement of all respondents away from their original homes (see, for example, Evrard and Goudineau 2004), in this case sometimes several days travel away within the forest. Cultural connections were more readily described as relating to traditional, locally weaved clothing and to social relations and sharing within the village, which had limited links to the forest. Spiritual connections to the forests had reportedly declined for both Buddhists and animists. For example, important spiritual ancestral beliefs no longer related to trees or mountains in the forests as in the past but were now most commonly associated with people's houses and specific areas close to the village. The offerings provided to those spirits during rituals were no longer wild animals but domestic ones. However, this also meant that people did not fear cutting forest where the presence of spirits previously reduced its likelihood. Each village retained access to forests within their land so that foraging and hunting for a wide variety of foods and materials were still commonly practiced by all households, though almost all were available for collection outside of the protected area in fields, fallows, riparian habitats, or village forests. However, the availability, particularly of larger animals such as wild pigs and deer was reported to have decreased considerably. Rodents, birds, and squirrels trapped in agricultural land or village land, fish from nearby rivers, and domestic animals had taken their place in most people's diets, although $33 \%$ of interview respondents in Khorn Ngua still hunted large animals, $23 \%$ in Phon Song, and the fewest, $18 \%$ in Son Koua.

Socioeconomic data collected through semistructured interviews indicated that the material well-being of people from the 100 participating households increased considerably during the period 2004 to 2014 (Table 1). The public services underpinning well-being had improved because all three villages had gained communal resources of clean running water, electricity access, improved roads, schools, and health centers. At household level, incomes increased substantially as did education and asset ownership. Incomes increased primarily because of the introduction of maize as a cash crop through intermediary companies, which provided credit for inputs. Income from sale of locally collected natural resources (including bamboo shoots, grubs, grass to make brooms, fish, snails, river weed, and medicinal plants) was comparatively small, averaging 1.08 million Kip (approximately US\$132) compared to 7.15 million Kip (approximately US\$875) for farming income. Rising farming incomes were indicative of a broader trend of greater market links across the region. Livelihoods also diversified considerably over the period with 44 of the 100 participating households receiving income from nonfarm labor in 2014, half of which represented remittances from family members undertaking employment for part of the year outside of the region, commonly in factories or forestry. Nonfarm income came through occupations as teachers, soldiers, shop keepers, and traders. Poverty rates decreased substantially over the same period. The multidimensional poverty index fell by more than half, meaning that the average household was no longer classed as poor (Table 1). This change was driven largely by increasing asset ownership and education levels. The improvement was consistent across all three villages.

Increases in income and the extent of livelihood diversification differed between the three villages. Incomes were lowest and livelihoods relatively undiversified in Phon Song. Farming incomes were significantly lower than in Khorn Ngua (one-way analysis of variance, $\mathrm{p}<0.05, \mathrm{~F}=5.63)$ and in Son Khoua $(\mathrm{p}<$ $0.05, \mathrm{~F}=4.64)$. In Phon Song all households practiced farming, which produced the vast majority of their incomes. This greater incentive among villagers in Phon Song to seek additional land for farming within NEPL supports the findings from our spatial analysis that trade-offs with biodiversity conservation (in terms of average annual clearance of forests and fallows in the protected area) were highest in that village. In Phon Song livelihood diversification was least evident with just $33 \%$ of households receiving nonfarm income. This compared to $63 \%$ of households in Son Koua receiving nonfarm income, including $18 \%$ employed for occasional work through the ecotourism project, and $15 \%$ of households sampled there no longer farmed land at all because of a transition to trading. Income generation from sale of forest products was highest and most widespread in Khorn Ngua, practiced in $100 \%$ of households, compared to $87 \%$ in Phon Song and just $40 \%$ in Son Koua (Table 1).

\section{Qualitative environmental justice research}

We present results of qualitative interviews exploring claims around environmental justice. We focus on key examples of views held in the study villages from each of the three interrelated dimensions of procedure, distribution, and recognition, to illustrate prominent social feedbacks and their implications for the governance of ecosystem service trade-offs, particularly between conservation and local livelihoods (summarized in Table 3).

\section{Procedure}

In practice, formal rules had been replaced by a system of informal governance:

The processes through which decisions were made and implemented played an important part in the way they were perceived and how people reacted to them. Respondents voiced dissatisfaction with the lack of influence at the outset of protected area establishment and during subsequent decisions about boundaries. Consultation was considered to have entailed informing local inhabitants of predetermined rules rather than considering their views. Villagers felt uncertainty of resource tenure as a consequence, fearing the announcement of further limitations to their access, particularly because many had lost land in the past, without the possibility to challenge the decision. There was also a lack of ongoing dialogue between protected area managers and locals, who felt they had little ability to raise issues and discuss them.

When we have a meeting the head just spreads government news. Some agree, some disagree with what they say and it is hard to find agreeable solutions. At meetings, the village head talks about the protected area. He said that this mountain here has become part of the protected area so we can't cut the trees there. Ten agreed with him but 20 households disagreed with him. We said we need to farm there, but they still went ahead and decided to protect it instead!

Because of the perceived unfairness of rules and inability to influence them, locals instead sought to informally negotiate with local authorities and individual protected area staff so as to adapt regulations and gain unofficially sanctioned access to land and resources. Such negotiation of access to historically farmed areas, 
Table 3. Summary of justice issues as perceived by villagers around Nam Et-Phou Louey National Protected Area, and resulting social feedbacks.

\begin{tabular}{ll}
\hline \hline $\begin{array}{l}\text { Justice issue relating to ecosystem } \\
\text { governance }\end{array}$ & Perspective of local people, cognitive response \\
\hline $\begin{array}{l}\text { Procedure } \\
\text { Informal procedures govern access, } \\
\text { not only formal rules }\end{array}$ & $\begin{array}{l}\text { Rules determined with minimal participation or influence, } \\
\text { including no access to previously used land. Limited } \\
\text { ongoing dialogue or potential to adapt formal rules. }\end{array}$
\end{tabular}

Relative inability of poorest to access land and resources
Poorest, least powerful households have weak ability to influence meetings or informal negotiation, therefore suffer fines, punishments disproportionately, and are relatively unable to access land both inside and outside the protected area. Lack of grievance mechanism to make claims.

Conservation supported in principle, and wide array of perceived benefits. However, burden of more immediate livelihood restrictions considered unfair, in part due to broken promises of support.

High relative social impacts of conservation for villagers in core areas where boundaries and regulations most restrictive. Limitations to farming land curtail ability to lead a reasonable quality of life. Benefits not targeted here to compensate.

Tourism brings local benefits through jobs, trade and revenue sharing so benefits potentially outweigh costs.

Behavioral response/social feedback

People seek negotiation of change to rules through local authorities and individual protected area staff. Some obtain sanctioned use of land in protected area, permission to expand certain uses into protected area, avoidance of punishment.

Claims for equal access to land and for more transparent, consistent rule enforcement made through meetings. Dissatisfaction expressed with village leadership, letters sent to authorities, building resentment with conservation.

Rule breaking accepted by most villagers without stigma.

Lack of support for protected area rules. Active involvement in or support for conservation is stigmatized.

Dependency of ecotourism revenue sharing on rule compliance means illegal hunting in protected area is stigmatized, a positive feedback. Some dissatisfied with elite capture and inability of the poorest to benefit from employment opportunities.

People wish for higher incomes through diversification, to grow cash crops, rear livestock and to invest in education, modern housing and technology. Reconnection to old village land and access to new areas would facilitate locally valued development. Allocation of land, restricted through protected area boundaries, impinges on ability to meet these aspirations.
Dissatisfaction voiced with lack of livelihood support appropriate to changing priorities received through conservation organizations and partners.

Claims to protected area land, particularly land around old villages and fertile, flat land increasing in all villages. to allow clearance of new land with limited forest cover, flat land suited to more continuous farming, or for establishment of new grazing areas within NEPL was strongly evident in Phon Song and to a lesser extent in the other two villages. In practice, therefore, the formal rules governing the protected area appear to have little bearing on those that are implemented and considered to form the legitimate governance regime, despite the presence of ranger camps close to the villages. Villagers' responses suggested that NEPL staff had even adapted to the claims of villagers and extent of rule-breaking by weakening the enforcement of rules or realigning them.

In the past when NEPL staff came and you took a risk in cutting trees they would fine you a lot of money. But it's better now, they allow people to use more land around. It depends on who you know, if you know the process from when they divided it up in the past, then you are likely to be able to have some.
Relative inability of poorest to access land and resources results in dissatisfaction and complaint:

The informal negotiation of access to resources in NEPL is not a collective exercise performed at the village level or on behalf of all inhabitants, but instead depends upon the power and influence of individuals or groups. The dominance of informal governance in practice results in exacerbated protected area impacts on the poorest and most marginal. Although some more powerful people could negotiate with local authorities or forest guards to use land inside the protected area, villagers who were poorer and less powerful were less able to successfully retain access or avoid fines: "The wealthy can risk to go out and claim land as theirs and the rest of us are stuck without."

This dominance of informal rules was connected to issues of low transparency, inconsistency of rule application and enforcement, weak accountability for decision making, and extensive corruption. Because of their weaker ability to influence decisions, 
poorer households suffer disproportionately low benefits and higher costs (highlighting overlap between procedure and distribution dimensions). Although interhousehold differences, trends in land holdings, and other distributional implications for poorer families were captured through well-being assessment, the sense of injustice related to these procedural inequalities was not clearly highlighted in our well-being data. The environmental justice research revealed that in response, some sought to protest against this perceived injustice, primarily through voicing dissatisfaction at meetings or writing regularly to NEPL authorities, representing a form of social feedback.

\section{Last year I wrote to NEPL managers to let me grow rice or maize near the road, by the protected area and they said they don't allow anyone to do that. But when someone else went and cut the trees down and planted it up they did nothing! So, I will write to them next year and ask again. Those who have big lands already can become rich, that's the only explanation for it.}

\section{Distribution}

Costs of protected area perceived to be unjust and rules therefore illegitimate:

Despite upward trends in well-being presented above, and the perception that benefits of conservation outweighed associated costs in the long term, respondents felt that the more immediate impediment conservation had caused to their livelihoods was unfair and had been insufficiently offset by material compensation. Of 100 respondents, 90 perceived conservation rules to be too strict, with most voicing dissatisfaction with impacts on their farming practices. This perception was caused in part by promises of livelihood support reportedly made by protected area staff at the time boundaries were demarcated, which were not considered to have been fulfilled.

The conservation staff said when they came they will provide funding, all kinds of support to us. So, everyone agreed to it, but nothing came.

Although all supported conservation in principle, rules were considered unrealistic curtailments of easily available livelihood opportunities, resulting in social feedbacks (Table 3). For example, rule-breaking was therefore commonly perceived as legitimate behavior.

\section{If someone hunts there (in the protected area) they get fined 2-5 million Kip for it. If the staff see them it is 2- 5 million per person. But some people, if they don't get caught they can bring back a sambar deer and it's $O K$. There are no fines in the village.}

Perceptions of the protected area differed both between and within villages, as did the resulting social feedbacks. As uncovered through the well-being assessment, those in Phon Song perceived high costs relative to other villages, without receiving appropriately compensating benefits. In addition, the justice analysis revealed that in Phon Song, villagers who played a role in protected area management and in enforcing the unpopular rules, were subjected to social stigma.

When I worked with the protected area some people didn't understand it, so I fought with people a bit. Some threw rocks at my house. I was told I would get a tip if I caught people hunting. But even though I did they didn't pay anything. And now people here think I'm a bad person, they don't understand. So I stopped working for conservation recently.

In Son Koua, where an ecotourism project operated, most respondents expressed support for conservation rules, despite strict rules in place, and $63 \%$ attributed this to the benefits or potential gains to be received from ecotourism. Because of the provision of employment opportunities and the division of a small amount of revenue conditional on adherence to rules, inhabitants of Son Koua wished to see hunters caught and punished, in contrast to Phon Song.

There are some deer killed every year, but we can't catch the poachers. Last year the tourists came to visit, then they encountered the head of a dead deer on the river bank. They should be fined, because they are breaking the rules, and because they are killing prohibited animals.

This view was not unanimously held by all interviewees in Son Koua. Only seven of those 40 had received employment on the ecotourism project and several poorer respondents expressed disenchantment because of elite capture and the lack of benefits that they received. During our research NEPL staff were observed stating during a meeting that they only hired wealthier people because when people from poor households were employed, they failed to turn up for work because of other priorities.

\section{Recognition}

Changing identities leads to changing perceptions of and response to protected area impacts:

The identities and values of villagers living around NEPL were changing rapidly because of economic and social changes. Villagers no longer identified as subsistence farmers, dependent on rice harvests, hunting and foraging for food, medicines, fuel, and shelter. In the space of a generation they had become commercial farmers, many with diversified incomes and some leaving farming altogether. As detailed through well-being research they wished to fund their children's education to enable them to leave farming, improve their housing with modern materials, use modern medicines, and travel to towns and cities. To attain the higher incomes and to raise finance to meet these material wants, people displayed a propensity to react to economic opportunities arising in agriculture or for sale of natural resources and forest products, and numbers of international traders from China and Vietnam entering the area increased. Additionally, villagers wished to spend less time farming the land and so aspired to grow low intensity cash crops or to raise livestock.

In response to questions exploring environmental justice, villagers complained frequently of the lack of ongoing or two-way dialogue between NEPL managers and villagers. This paucity of engagement meant that conservation organizations fail to respond to the changing aspirations of local inhabitants. As a resulting social feedback, people began to seek access not to forested hills for growing rice or maize but instead seek out flatter, more productive land or grasslands to meet their new ambitions. Contrary to the general trends in well-being, extensive claims to land in the park had arisen in all three villages and were increasing. In Khorn Ngua, people wished to build a road to open up areas on the edge of NEPL, and seek to improve irrigation to provide 
more rice paddies. In Son Koua, despite the benefits of ecotourism, study respondents voiced claims for land at their old village inhabited prior to relocation, Hua Muang, which lies inside NEPL and had become the site of an ecotourism camp. New temporary settlements had been recently established close to the NEPL border to facilitate more cultivation and grazing there. In Phon Song, several new settlements had been established inside NEPL to enable livestock to graze in areas further away from the village and crops.

\section{The ranger camp is now the area the villagers used to live in. People here in Son Koua thought they still have rights to go and to use that area in Hua Muang. But the NEPL management stopped them and they feel like they have lost their rights of access to use those large areas of flat land.}

\section{DISCUSSION}

This study combined spatial analysis of land use change, mixed method assessment of well-being, and qualitative exploration of environmental justice to provide insights into ecosystem service trade-offs. Our results illustrate the value of adding an environmental justice approach to ecosystem services frameworks to elicit people's cognitive and behavioral reactions to ecosystem governance, otherwise termed social feedbacks. Our findings from spatial analysis and well-being assessment painted a picture of positive development and conservation trends, with limited tradeoffs between the protected area and local people's well-being. Deforestation levels were stable and relatively low in core areas. During the same period, smallholders and their farming had become commercialized through cash crops, international market links, financing, and mechanization, which fuelled extensive, inclusive development. Additionally, local practices were shifting from forest-dependent, subsistence lifestyles toward more diversified and increasingly off-farm livelihoods. In contrast, results from environmental justice research revealed profound trade-offs between conservation and local practices. The social feedbacks uncovered indicated threats to conservation yet also implied a variety of additional pathways through which to satisfy the rights, needs, and interests of local people and reconcile tradeoffs (Table 3). In particular, our findings highlight deficiencies relating to procedure and recognition that were overlooked by spatial analyses or well-being research. Resulting social feedbacks included violent repercussions for villagers' participating in conservation work, negotiation of informal access with alternative authorities, and re-emergence of claims to old village lands. Studies into stakeholders' diverse and changing claims are increasingly exposing perceived equity or in/justice as powerful drivers of human behavior in relation to environmental governance (He and Sikor 2015, Martin et al. 2016, Schreckenberg et al. 2016, Levine et al. 2017).

We do not propose a comprehensive categorization of social feedbacks. The examples provided support the general categories presented by Pascual et al. (2014). Instead we emphasize the importance of employing broad definitions of social feedbacks and suitable methodologies to draw out practical recommendations for addressing trade-offs for both human well-being and conservation. Our study exposed a diverse array of feedbacks, including responses in formal and informal processes, and both direct and subtle indirect ways through which people can resist, undermine, or manipulate rules and policies. Expression of those feedbacks was influenced by the power relations between social groups and authorities. These behavioral facets of resistance have been well documented in social and political sciences (Scott 1986), including in relation to conservation (Norgrove and Hulme 2006). Some social feedbacks, such as open demonstration or debate at meetings may be easily observable whereas social interactions influencing stigmatization of activities may be subtler (Mathers and Novelli 2007). These complex social foundations of and means of expressing feedbacks imply that researching them necessitates inclusion of an interpretive methodology with attention to researcher-participant relations. We find it useful, in the context of ecosystem governance, to differentiate between cognitive and behavioral aspects of feedbacks, and whether they stem from material or subjective aspects of a person's well-being or are primarily influenced by political, social, environmental, and economic contextual factors. Indeed, we found environmental justice research to be highly compatible with and complementary to approaches to study well-being and capabilities, as noted by other environmental governance scholars (Schlosberg and Carruthers 2010, Edwards et al. 2016). Some studies have incorporated very broad definitions of well-being that capture some of these dynamics (Biedenweg et al. 2017). However, cursory recommendations to "sketch links" between ecosystem services and well-being are evident in many ecosystem assessment protocols (see for example Ash et al. 2010) and are inadequate to inform management of trade-offs in complex and dynamic contexts.

\section{Implications for conservation and development practice}

The rapidity of social and economic change for local people, transforming from subsistence farmers and hunter-gatherer societies to commercialized, connected rural communities over the course of a generation, is not uncommon in rural areas of developing countries (Wittemyer et al. 2008, Leach et al. 2010). This extent of change occurring in rural parts of the developing world highlights the utility of more adaptive forms of ecosystem, landscape, or protected area governance, with ongoing two-way dialogue between stakeholders, responsive management structures, and iterative decision making composing elements of comanagement (Armitage et al. 2009, Sikor 2013, Moreno et al. 2014, Martin et al. 2015, Bennett 2016). Our results indicate that enhancing the transparency of rules and procedures, consistency of enforcement, and accountability levels are prerequisites to gain greater local support for conservation, and that establishment of ongoing dialogue with diverse groups of local people in protected area decision making will be key steps toward addressing some of the negative social feedbacks that currently threaten biodiversity within protected areas.

Around NEPL, a top-down system of governance has prevailed. Components of adaptive management to counter issues that undermine conservation and contribute to the well-being of vulnerable local populations remain absent. In forest-adjacent communities, land use planning procedures involve short-term interaction (approximately one week) with community representatives to allocate land to different uses at the village scale. But in overlooking intra-village allocation, land use planning often fails to pay adequate attention to issues of tenure, access rights, or interests of the poorest and most marginal. In practice limited capacity, participation and longstanding political issues 
hamper their effectiveness (Bourgoin et al. 2012). In the absence of follow-up meetings, agreed solutions quickly lose relevance (Lestrelin et al. 2012), or agreed boundaries may be overridden by other boundary-setting exercises (Broegaard et al. 2017b). As such they do not act as forums through which decision making procedures may be improved or through which complex or entrenched injustices addressed. To achieve such gains for conservation and for the well-being of rural inhabitants it will be critical to place people's perceptions of governance at the centre of these issues rather than continuing to treat them as subjects of environmental education or conservation policy. Gaining local support for conservation is critical in regulating local resource extraction as well as aiding the fight against wildlife crime, and large scale extractive industries such as logging, which are prevalent in this border area with Vietnam (Johnson et al. 2016). More effective enforcement alone would be unlikely to achieve the desired improvements in conservation effectiveness. Attempts to develop more embedded collaborative governance regimes in other Lao protected areas appear to be enhancing effectiveness and may provide valuable lessons going forward (de Koning et al. 2016).

Innovative research addressing ecosystem service trade-offs has employed multistakeholder processes to coproduce adaptive solutions (Abunge et al. 2013, King et al. 2015, Reyers et al. 2015, Dedeurwaerdere et al. 2016). Bringing such engagement into conservation practice could potentially be realized through refocusing current engagement, education, and social marketing practices rather than demanding entirely additional resources. More inclusive, transparent, and accountable collaborative governance approaches are at the heart of rhetoric behind emerging international conservation policy goals, including rights-based approaches to conservation (Jonas et al. 2014), landscape approaches (Sayer et al. 2013), equity as a goal for protected area governance in the Convention on Biological Diversity (Hill et al. 2015), and in the sustainable development goals (Griggs et al. 2013). The importance of social research in sustainability science is well recognised (Hicks et al. 2016), and the findings of our study emphasize the importance of social feedbacks and environmental justice as additional social concepts to be embraced.

Responses to this article can be read online at: http://www.ecologyandsociety.org/issues/responses. $\mathrm{php} / 9481$

\footnotetext{
Acknowledgments:

We thank the participants whose time and openness made this study possible. We thank our Principal Investigator Thomas Sikor for his guidance, colleagues from the Faculty of Forestry at the National University of Laos for logistical support and research assistance, and The Wildlife Conservation Society of Laos and Lao Government staff for their contribution to the research. The work was funded by the Ecosystem Services for Poverty Alleviation (ESPA) programme, grant number NE/L001411/1. The ESPA programme is funded by the Department for International Development (DFID), the Economic and Social Research Council (ESRC) and the Natural Environment Research Council (NERC).
}

\section{LITERATURE CITED}

Abunge, C., S. Coulthard, and T. M. Daw. 2013. Connecting marine ecosystem services to human well-being: insights from participatory well-being assessment in Kenya. Ambio 42:1010-1021. http://dx.doi.org/10.1007/s13280-013-0456-9

Albert, C., J. Aronson, C. Fürst, and P. Opdam. 2014. Integrating ecosystem services in landscape planning: requirements, approaches, and impacts. Landscape Ecology 29:1277-1285. http://dx.doi.org/10.1007/s10980-014-0085-0

Alkire, S., and M. E. Santos. 2014. Measuring acute poverty in the developing world: robustness and scope of the multidimensional poverty index. World Development 59:251-274. http://dx.doi.org/10.1016/j.worlddev.2014.01.026

Armitage, D. R., R. Plummer, F. Berkes, R. I. Arthur, A. T. Charles, I. J. Davidson-Hunt, A. P. Diduck, N. C. Doubleday, D. S. Johnson, M. Marschke, P. McConney, E. W. Pinkerton, and E. K. Wollenberg. 2009. Adaptive co-management for socialecological complexity. Frontiers in Ecology and the Environment 7:95-102. http://dx.doi.org/10.1890/070089

Ash, N., H. Blanco, C. Brown, K. Garcia, T. Henrichs, N. Lucas, C. Raudsepp-Hearne, R. D. Simpson, R. Scholes, T. Tomich, B. Vira, and M. Zurek. 2010. Ecosystems and human well-being: a manual for assessment practitioners. Island Press, Washington, D. C., USA.

Bandura, A. 1986. Social foundations of thought and action: a social cognitive theory. Prentice-Hall, Upper Saddle River, New Jersey, USA.

Bennett, N. J. 2016. Using perceptions as evidence to improve conservation and environmental management. Conservation Biology 30:582-592. http://dx.doi.org/10.1111/cobi.12681

Berbés-Blázquez, M., J. A. González, and U. Pascual. 2016. Towards an ecosystem services approach that addresses social power relations. Current Opinion in Environmental Sustainability 19:134-143. http://dx.doi.org/10.1016/j.cosust.2016.02.003

Biedenweg, K., H. Harguth, and K. Stiles. 2017. The science and politics of human well-being: a case study in cocreating indicators for Puget Sound restoration. Ecology and Society 22(3):11. http:// dx.doi.org/10.5751/es-09424-220311

Boonstra, W. 2016. Conceptualizing power to study socialecological interactions. Ecology and Society 21(1):21. http://dx. doi.org/10.5751/es-07966-210121

Bourgoin, J., J.-C. Castella, D. Pullar, G. Lestrelin, and B. Bouahom. 2012. Toward a land zoning negotiation support platform: "tips and tricks" for participatory land use planning in Laos. Landscape and Urban Planning 104:270-278. http://dx.doi. org/10.1016/j.landurbplan.2011.11.008

Breiman, L. 2001. Random forests. Machine Learning 45:5-32. http://dx.doi.org/10.1023/A:1010933404324

Broegaard, R. B., L. V. Rasmussen, N. Dawson, O. Mertz, T. Vongvisouk, and K. Grogan. 2017a. Wild food collection and nutrition under commercial agriculture expansion in agricultureforest landscapes. Forest Policy and Economics. http://dx.doi. org/10.1016/j.forpol.2016.12.012 
Broegaard, R. B., T. Vongvisouk, and O. Mertz. $2017 b$. Contradictory land use plans and policies in Laos: tenure security and the threat of exclusion. World Development 89:170-183. http:// dx.doi.org/10.1016/j.worlddev.2016.08.008

Carpenter, S. R., H. A. Mooney, J. Agard, D. Capistrano, R. S. DeFriese, S. Díaz, T. Dietz, A. K. Duraiappah, A. Oteng-Yeboahi, H. Miguel Pereira, C. Perrings, W. V. Reid, J. Sarukhan, R. J. Scholes, and A. Whyte. 2009. Science for managing ecosystem services: beyond the Millennium Ecosystem Assessment. Proceedings of the National Academy of Sciences 106:1305-1312. http://dx.doi.org/10.1073/pnas.0808772106

Castella, J.-C., G. Lestrelin, C. Hett, J. Bourgoin, Y. R. Fitriana, A. Heinimann, and J.-L. Pfund. 2013. Effects of landscape segregation on livelihood vulnerability: moving from extensive shifting cultivation to rotational agriculture and natural forests in northern Laos. Human Ecology 41:63-76. http://dx.doi. org/10.1007/s10745-012-9538-8

Clements, T., A. John, K. Nielsen, D. An, S. Tan, and E. MilnerGulland. 2010. Payments for biodiversity conservation in the context of weak institutions: comparison of three programs from Cambodia. Ecological Economics 69:1283-1291. http://dx.doi. org/10.1016/j.ecolecon.2009.11.010

Coulthard, S., D. Johnson, and J. A. McGregor. 2011. Poverty, sustainability and human well-being: a social well-being approach to the global fisheries crisis. Global Environmental Change 21:453-463. http://dx.doi.org/10.1016/j.gloenvcha.2011.01.003

Dawson, N., and A. Martin. 2015. Assessing the contribution of ecosystem services to human well-being: a disaggregated study in western Rwanda. Ecological Economics 117:62-72. http://dx.doi. org/10.1016/j.ecolecon.2015.06.018

de Groot, R. S., R. Alkemade, L. Braat, L. Hein, and L. Willemen. 2010. Challenges in integrating the concept of ecosystem services and values in landscape planning, management and decision making. Ecological Complexity 7:260-272. http://dx.doi. org/10.1016/j.ecocom.2009.10.006

de Koning, M., J. W. K. Parr, S. Sengchanthavong, and S. Phommasane. 2016. Collaborative governance improves management effectiveness of Hin Nam No National Protected Area in Central Lao PDR. Parks 22:27-40. http://dx.doi. org/10.2305/IUCN.CH.2016.PARKS-22-2MdK.en

de Lange, E., E. Woodhouse, and E. J. Milner-Gulland. 2016. Approaches used to evaluate the social impacts of protected areas. Conservation Letters 9:327-333. http://dx.doi.org/10.1111/ conl.12223

Deci, E. L., and R. M. Ryan. 2008. Hedonia, eudaimonia, and well-being: an introduction. Journal of Happiness Studies 9:1-11. http://dx.doi.org/10.1007/s10902-006-9018-1

Dedeurwaerdere, T., J. Admiraal, A. Beringer, F. Bonaiuto, L. Cicero, P. Fernandez-Wulff, J. Hagens, J. Hiedanpää, P. Knights, E. Molinario, et al. 2016. Combining internal and external motivations in multi-actor governance arrangements for biodiversity and ecosystem services. Environmental Science \& Policy 58:1-10. http://dx.doi.org/10.1016/j.envsci.2015.12.003
Dex, S. 1995. The reliability of recall data: a literature review. Bulletin of Sociological Methodology / Bulletin de Methodologie Sociologique 49:58-89. http://dx.doi.org/10.1177/075910639504900105

Edwards, G. A. S., L. Reid, and C. Hunter. 2016. Environmental justice, capabilities, and the theorization of well-being. Progress in Human Geography 40(6). http://dx.doi.org/10.1177/0309132515620850

Evrard, O., and Y. Goudineau. 2004. Planned resettlement, unexpected migrations and cultural trauma in Laos. Development and Change 35:937-962. http://dx.doi.org/10.1111/j.1467-7660.2004.00387. $\underline{\mathrm{x}}$

Galafassi, D., T. M. Daw, L. Munyi, K. Brown, C. Barnaud, and I. Fazey. 2017. Learning about social-ecological trade-offs. Ecology and Society 22(1):2. http://dx.doi.org/10.5751/es-08920-220102

Gough, I., and J. A. McGregor. 2007. Wellbeing in developing countries: from theory to research. Cambridge University Press, New York, New York, USA. http://dx.doi.org/10.1017/ $\underline{\text { cbo9780511488986 }}$

Griggs, D., M. Stafford-Smith, O. Gaffney, J. Rockström, M. C. Öhman, P. Shyamsundar, W. Steffen, G. Glaser, N. Kanie, and I. Noble. 2013. Policy: sustainable development goals for people and planet. Nature 495:305-307. http://dx.doi.org/10.1038/495305a

Guerry, A. D., S. Polasky, J. Lubchenco, R. Chaplin-Kramer, G. C. Daily, R. Griffin, M. Ruckelshaus, I. J. Bateman, A. Duraiappah, and T. Elmqvist. 2015. Natural capital and ecosystem services informing decisions: from promise to practice. Proceedings of the National Academy of Sciences 112:7348-7355. http://dx.doi.org/10.1073/pnas. 1503751112

Haidt, J. 2007. The new synthesis in moral psychology. Science 316:998-1002. http://dx.doi.org/10.1126/science.1137651

He, J., and T. Sikor. 2015. Notions of justice in payments for ecosystem services: insights from China's Sloping Land Conversion Program in Yunnan Province. Land Use Policy 43:207-216. http://dx.doi.org/10.1016/j.landusepol.2014.11.011

Hein, L., K. van Koppen, R. S. de Groot, and E. C. van Ierland. 2006. Spatial scales, stakeholders and the valuation of ecosystem services. Ecological Economics 57:209-228. http://dx.doi. org/10.1016/j.ecolecon.2005.04.005

Hett, C., J.-C. Castella, A. Heinimann, P. Messerli, and J.-L. Pfund. 2012. A landscape mosaics approach for characterizing swidden systems from a REDD+ perspective. Applied Geography 32:608-618. http://dx.doi.org/10.1016/j.apgeog.2011.07.011

Hicks, C. C., A. Levine, A. Agrawal, X. Basurto, S. J. Breslow, C. Carothers, S. Charnley, S. Coulthard, N. Dolsak, J. Donatuto, et al. 2016. Engage key social concepts for sustainability. Science 352:38-40. http://dx.doi.org/10.1126/science.aad4977

Hill, R., G. A. Dyer, L. M. Lozada-Ellison, A. Gimona, J. MartinOrtega, J. Munoz-Rojas, and I. J. Gordon. 2015. A socialecological systems analysis of impediments to delivery of the Aichi 2020 Targets and potentially more effective pathways to the conservation of biodiversity. Global Environmental Change 34:22-34. http://dx.doi.org/10.1016/j.gloenvcha.2015.04.005

Howe, C., H. Suich, B. Vira, and G. M. Mace. 2014. Creating winwins from trade-offs? Ecosystem services for human well-being: 
a meta-analysis of ecosystem service trade-offs and synergies in the real world. Global Environmental Change 28:263-275. http:// dx.doi.org/10.1016/j.gloenvcha.2014.07.005

Huta, V., and A. S. Waterman. 2014. Eudaimonia and its distinction from hedonia: developing a classification and terminology for understanding conceptual and operational definitions. Journal of Happiness Studies 15:1425-1456. http://dx. doi.org/10.1007/s10902-013-9485-0

Johnson, A. 2012. A landscape summary for the Nam Et-Phou Louey National Protected Area, Lao PDR. Pages 73-90 in T. C. H. Sunderland, J. Sayer, and H. Minh-Ha, editors. Evidence-based conservation: lessons from the Lower Mekong. Earthscan, Routledge, London.

Johnson, A., J. Goodrich, T. Hansel, A. Rasphone, S. Saypanya, C. Vongkhamheng, Venevongphet, and S. Strindberg. 2016. To protect or neglect? Design, monitoring, and evaluation of a law enforcement strategy to recover small populations of wild tigers and their prey. Biological Conservation 202:99-109. http://dx.doi. org/10.1016/j.biocon.2016.08.018

Jonas, H., D. Roe, and J. E. Makagon. 2014. Human rights standards for conservation: an analysis of responsibilities, rights and redress for just conservation. IIED Issue Paper. International Institute for Environment and Development, London, UK.

King, E., J. Cavender-Bares, P. Balvanera, T. H. Mwampamba, and S. Polasky. 2015. Trade-offs in ecosystem services and varying stakeholder preferences: evaluating conflicts, obstacles, and opportunities. Ecology and Society 20(3):25. http://dx.doi. org/10.5751/es-07822-200325

Kollmuss, A., and J. Agyeman. 2002. Mind the gap: why do people act environmentally and what are the barriers to proenvironmental behavior? Environmental Education Research 8:239-260. http://dx.doi.org/10.1080/13504620220145401

Lawler, J. J., D. J. Lewis, E. Nelson, A. J. Plantinga, S. Polasky, J. C. Withey, D. P. Helmers, S. Martinuzzi, D. Pennington, and V. C. Radeloff. 2014. Projected land-use change impacts on ecosystem services in the United States. Proceedings of the National Academy of Sciences 111:7492-7497. http://dx.doi. org/10.1073/pnas.1405557111

Leach, M., J. Rockström, P. Raskin, I. C. Scoones, A. C. Stirling, A. Smith, J. Thompson, E. Millstone, A. Ely, E. Arond, C. Folke, and P. Olsson. 2012. Transforming innovation for sustainability. Ecology and Society 17(2):11. http://dx.doi.org/10.5751/ es-04933-170211

Leach, M., I. Scoones, and A. Stirling. 2010. Dynamic sustainabilities: technology, environment, social justice. Earthscan, London, UK.

Lele, S., O. Springate-Baginski, R. Lakerveld, D. Deb, and P. Dash. 2013. Ecosystem services: origins, contributions, pitfalls, and alternatives. Conservation and Society 11:343-358. http://dx. doi.org/10.4103/0972-4923.125752

Lestrelin, G., J.-C. Castella, and J. Bourgoin. 2012. Territorialising sustainable development: the politics of land-use planning in Laos. Journal of Contemporary Asia 42:581-602. http://dx.doi. org/10.1080/00472336.2012.706745
Levine, J., M. Muthukrishna, K. M. A. Chan, and T. Satterfield. 2017. Sea otters, social justice, and ecosystem-service perceptions in Clayoquot Sound, Canada. Conservation Biology 31:343-352. http://dx.doi.org/10.1111/cobi.12795

Mariki, S. B., H. Svarstad, and T. A. Benjaminsen. 2015. Elephants over the cliff: explaining wildlife killings in Tanzania. Land Use Policy 44:19-30. http://dx.doi.org/10.1016/j. landusepol.2014.10.018

Martin, A., A. Akol, and N. Gross-Camp. 2015. Towards an explicit justice framing of the social impacts of conservation. Conservation and Society 13:166-178. http://dx.doi. org/10.4103/0972-4923.164200

Martin, A., B. Coolsaet, E. Corbera, N. M. Dawson, J. A. Fraser, I. Lehman, and I. Rodriguez. 2016. Justice and conservation: the need to incorporate recognition. Biological Conservation 197:254-261. http://dx.doi.org/10.1016/j.biocon.2016.03.021

Mathers, A., and M. Novelli. 2007. Researching resistance to neoliberal globalization: engaged ethnography as solidarity and praxis. Globalizations 4:229-249. http://dx.doi.org/10.1080/14747730701345259

McShane, T. O., P. D. Hirsch, T. C. Trung, A. N. Songorwa, A. Kinzig, B. Monteferri, D. Mutekanga, H. V. Thang, J. L. Dammert, M. Pulgar-Vidal, M. Welch-Devine, J. P. Brosius, P. Coppolillo, and S. O'Connor. 2011. Hard choices: making tradeoffs between biodiversity conservation and human well-being. Biological Conservation 144:966-972. http://dx.doi.org/10.1016/j. biocon.2010.04.038

Moreno, J., I. Palomo, J. Escalera, B. Martín-López, and C. Montes. 2014. Incorporating ecosystem services into ecosystembased management to deal with complexity: a participative mental model approach. Landscape Ecology 29:1407-1421. http:// dx.doi.org/10.1007/s10980-014-0053-8

Nelson, E., G. Mendoza, J. Regetz, S. Polasky, H. Tallis, D. R. Cameron, K. M. A. Chan, G. C. Daily, J. Goldstein, P. M. Kareiva, E. Lonsdorf, R. Naidoo, T. H. Ricketts, and M. Shaw. 2009. Modeling multiple ecosystem services, biodiversity conservation, commodity production, and tradeoffs at landscape scales. Frontiers in Ecology and the Environment 7:4-11. http://dx.doi. org/10.1890/080023

Norgaard, R. B. 2010. Ecosystem services: from eye-opening metaphor to complexity blinder. Ecological Economics 69:1219-1227. http://dx.doi.org/10.1016/j.ecolecon.2009.11.009

Norgrove, L., and D. Hulme. 2006. Confronting conservation at Mount Elgon, Uganda. Development and Change 37:1093-1116. http://dx.doi.org/10.1111/j.1467-7660.2006.00514.x

Opdam, P., J. I. Nassauer, Z. Wang, C. Albert, G. Bentrup, J.-C. Castella, C. McAlpine, J. Liu, S. Sheppard, and S. Swaffield. 2013. Science for action at the local landscape scale. Landscape Ecology 28:1439-1445. http://dx.doi.org/10.1007/s10980-013-9925-6

Pascual, U., J. Phelps, E. Garmendia, K. Brown, E. Corbera, A. Martin, E. Gomez-Baggethun, and R. Muradian. 2014. Social equity matters in payments for ecosystem services. Bioscience 64:1027-1036. http://dx.doi.org/10.1093/biosci/biu146 
Polishchuk, Y., and F. Rauschmayer. 2012. Beyond "benefits"? Looking at ecosystem services through the capability approach. Ecological Economics 81:103-111. http://dx.doi.org/10.1016/j. ecolecon.2012.06.010

QSR. 2012. NVivo qualitative data analysis software; Version 10. QSR International Pty Ltd, Doncaster, Australia.

Rasmussen, L. V., A. E. Christensen, F. Danielsen, N. Dawson, A. Martin, O. Mertz, T. Sikor, S. Thongmanivong, and P. Xaydongvanh. 2017. From food to pest: conversion factors determine switches between ecosystem services and disservices. Ambio 46:173-184. http://dx.doi.org/10.1007/s13280-016-0813-6

Rasmussen, L. V., O. Mertz, A. E. Christensen, F. Danielsen, N. Dawson, and P. Xaydongvanh. 2016. A combination of methods needed to assess the actual use of provisioning ecosystem services. Ecosystem Services 17:75-86. http://dx.doi.org/10.1016/j. ecoser.2015.11.005

Raudsepp-Hearne, C., G. D. Peterson, and E. M. Bennett. 2010. Ecosystem service bundles for analyzing tradeoffs in diverse landscapes. Proceedings of the National Academy of Sciences 107:5242-5247. http://dx.doi.org/10.1073/pnas.0907284107

Reyers, B., J. L. Nel, P. J. O'Farrell, N. Sitas, and D. C. Nel. 2015. Navigating complexity through knowledge coproduction: mainstreaming ecosystem services into disaster risk reduction. Proceedings of the National Academy of Sciences 112:7362-7368. http://dx.doi.org/10.1073/pnas.1414374112

Rodríguez, J. P., T. D. Beard Jr, E. M. Bennett, G. S. Cumming, S. J. Cork, J. Agard, A. P. Dobson, and G. D. Peterson. 2006. Trade-offs across space, time, and ecosystem services. Ecology and Society 11(1):28. http://dx.doi.org/10.5751/es-01667-110128

Sayer, J., T. Sunderland, J. Ghazoul, J.-L. Pfund, D. Sheil, E. Meijaard, M. Venter, A. K. Boedhihartono, M. Day, C. Garcia, C. van Oosten, L. E. Buck. 2013. Ten principles for a landscape approach to reconciling agriculture, conservation, and other competing land uses. Proceedings of the National Academy of Sciences 110:8349-8356. http://dx.doi.org/10.1073/pnas. 1210595110

Schlosberg, D. 2013. Theorising environmental justice: the expanding sphere of a discourse. Environmental Politics 22:37-55. http://dx.doi.org/10.1080/09644016.2013.755387

Schlosberg, D., and D. Carruthers. 2010. Indigenous struggles, environmental justice, and community capabilities. Global Environmental Politics 10:12-35. http://dx.doi.org/10.1162/ GLEP a 00029

Schreckenberg, K., P. Franks, A. Martin, and B. Lang. 2016. Unpacking equity for protected area conservation. Parks 22:11-26. http://dx.doi.org/10.2305/IUCN.CH.2016.PARKS-22-2KS. en

Scott, J. 1986. Everyday forms of peasant resistance. Journal of Peasant Studies 13:5-35. http://dx.doi.org/10.1080/03066158608438289

Sikor, T. 2013. The justices and injustices of ecosystem services. Routledge, London, UK.
Sikor, T., A. Martin, J. Fisher, and J. He. 2014. Toward an empirical analysis of justice in ecosystem governance. Conservation Letters 7:524-532. http://dx.doi.org/10.1111/ conl.12142

Stedman, R. C. 2002. Toward a social psychology of place: predicting behavior from place-based cognitions, attitude, and identity. Environment and Behavior 34:561-581. http://dx.doi. org/10.1177/0013916502034005001

Stern, P. C. 2000. New environmental theories: toward a coherent theory of environmentally significant behavior. Journal of Social Issues 56:407-424. http://dx.doi.org/10.1111/0022-4537.00175

UK-National Ecosystem Assessment (NEA). 2011. The UK National Ecosystem Assessment: technical report. UNEPWCMC, Cambridge.

Vongvisouk, T., R. B. Broegaard, O. Mertz, and S. Thongmanivong. 2016. Rush for cash crops and forest protection: neither land sparing nor land sharing. Land Use Policy 55:182-192. http://dx.doi.org/10.1016/j.landusepol.2016.04.001

Walker, G. 2009. Beyond distribution and proximity: exploring the multiple spatialities of environmental justice. Antipode 41:614-636. http://dx.doi.org/10.1111/j.1467-8330.2009.00691.x

Walker, G. 2012. Environmental justice: concepts, evidence and politics. Routledge, London, UK.

Wittemyer, G., P. Elsen, W. T. Bean, A. C. O. Burton, and J. S. Brashares. 2008. Accelerated human population growth at protected area edges. Science 321:123-126. http://dx.doi. org/10.1126/science. 1158900

Woodhouse, E., K. M. Homewood, E. Beauchamp, T. Clements, J. T. McCabe, D. Wilkie, and E. Milner-Gulland. 2015. Guiding principles for evaluating the impacts of conservation interventions on human well-being. Philosophical Transactions of the Royal Society B: Biological Sciences 370(1681). http://dx.doi. org/10.1098/rstb.2015.0103

Wu, J. 2013. Landscape sustainability science: ecosystem services and human well-being in changing landscapes. Landscape Ecology 28:999-1023. http://dx.doi.org/10.1007/s10980-013-9894-9 